\title{
Can Metal Levels be Measured at a Community Laboratory?
}

Phonthakorn Panichkul ${ }^{1,2}$, Henry Ho ${ }^{1 *}$, Robert H. Hopper $\mathrm{Jr}^{1}$ and C. Anderson Engh $\mathrm{Jr}^{1,3}$

${ }^{1}$ Anderson Orthopaedic Research Institute, Alexandria, VA, USA

${ }^{2}$ Bangkok Hospital Medical Center, Bangkok, Thailand

3 Inova Center for Joint Replacement at Mount Vernon Hospital, Alexandria, VA, USA

"Corresponding author: Henry Ho, MS, Anderson Orthopaedic Research Institute, 2501 Parkers Lane Suite 200, Alexandria, VA 22306, USA, Tel: (703) 892-6500; Fax: (703) 799-5989, E-mail: phhenry@yahoo.com

Rec date: January 21, 2015; Acc date: February 16, 2016; Pub date: February 27, 2016

Copyright: @ 2016 Panichkul P, et al. This is an open-access article distributed under the terms of the Creative Commons Attribution License, which permits unrestricted use, distribution, and reproduction in any medium, provided the original author and source are credited.

\section{Abstract}

Background: There remain concerns about the ability of community laboratories to accurately measure blood metal levels as one piece of the monitoring and treatment algorithms for patients with a metal-on-metal total hip arthroplasty (THA).

Question/purposes: The purpose of this study is to compare serum cobalt and chromium levels obtained from one group of patients at a single reference laboratory to levels from a different group of patients measured at multiple community laboratories.

Methods: We compare serum metal levels performed prospectively at a single reference laboratory on 57 patients to levels performed retrospectively on 160 patients in community laboratories. All patients had unilateral metal-on-metal bearing hips. Metal levels were measured at 1, 2, 3 and 5 years post-op.

Results: There was no difference between community and reference groups in mean values, median values or the number of cases with values greater than $7 \mu \mathrm{g} / \mathrm{L}$ at any time interval.

Conclusions: We conclude that metal level values drawn in the community are similar to values obtained in tightly controlled prospective studies.

Level of evidence: Level I, diagnostic study. See the Guidelines for Authors for a complete description of levels of evidence.

Keywords: Metal-on-metal; Metal ion; Metal level; Cobalt; Chromium; Total hip arthroplasty; Laboratory

\section{Introduction}

Blood metal levels are one piece of the monitoring and treatment algorithms for patients with a metal-on-metal (MOM) bearing total hip arthroplasty (THA) [1-3]. Elevated blood metal levels have been correlated with clinical symptoms, radiographic osteolysis and higher wear rates in hip arthroplasty [4-9].

Prospective randomized clinical trials of metal levels are typically designed with tightly controlled protocols for blood acquisition and analysis $[10,11]$. This is because metal level testing has been described as technically challenging [12]. In contrast, there have been case reports and retrospective studies that have included metal levels and the specimen acquisition or laboratory protocol are not as tightly controlled as the prospective randomized trials [13-16]. Recently, one recalled MOM implant manufacturer has turned to two national laboratory chains to perform metal level testing [17]. The wide variation in metal level testing protocols noted above and the absence of a consensus algorithm for managing patients with a MOM hip has at times been confusing for physicians who simply want to measure metal levels in their own patients.
The physician uncertainty about how to order metal levels, where to send the specimen and what to do with the result is a growing problem. MOM hips were used for $35 \%$ of hip arthroplasty cases performed in the United States during 2006 [18]. In United Kingdom, the use of MOM bearings increased rapidly after 2004 and peaked in 2008 [19]. Although MOM bearings are currently a very small percentage of THAs, there are a large number of patients who need ongoing evaluation and treatment. Metal levels are one piece of their care.

There is a need for blood metal level testing in the community and there remain concerns about the accuracy and precision of test results. To date, we are not aware of any studies that have compared metal levels measured at a single reference laboratory to levels measured by community laboratories. The purpose of this study is to compare serum cobalt and chromium levels obtained from one group of patients at a single reference laboratory to levels from a different group of patients measured at multiple community laboratories. Our hypothesis is that mean, median, and levels greater than 7 parts per billion would not be different for the two groups. If true, the results could increase patient and physician confidence in the values reported from their local laboratories. 
Page 2 of 6

We acknowledge from the outset that this study is not intended to address some of the larger controversies surrounding metal level testing in patients with a MOM bearing hip. Specifically, threshold values, what test (serum, whole blood or erythrocyte), or when metal levels should be performed. Our only goal is to compare serum cobalt and chromium metal levels from a reference laboratory to those measured at community laboratories.

\section{Materials and Methods}

Between 2001 to 2011, we ordered and obtained serum levels on 160 patients with a unilateral MOM THA. This group represents the "community" laboratory group. Patients in this group were given a prescription in the office as part of routine clinical follow-up. Prescriptions were given regardless of clinical symptoms or radiographic findings. The tests were obtained at time frames based on routine follow-up. There were 135 patients who had metal level measurements done only once, 24 patients who had levels measured twice, and one who had levels measured three times.

Between 2004 to 2011, 57 patients were enrolled in prospective randomized trials conducted at our institution, had a unilateral MOM bearing THA and had serum metal levels measured as part of the trial. This group represents the "reference" laboratory group. These patients typically had metal levels measured at multiple time intervals per their respective protocols. Seven patients had a single post-op level, 13 had two post-op levels, and 37 had three or more levels at different time intervals.

Patients in the reference group had blood drawn at a single site (Inova Mount Vernon Hospital, Alexandria, Virginia) and analysis at a single laboratory location (London Health Science Centre, Ontario, Canada) following a strict protocol. Patient blood samples were collected at specific follow up intervals including $1,2,3$, and 5 years post-op. All measurements were made using Inductively Coupled Plasma Mass Spectrometry (ICPMS) which is currently recognized as the preferred method for metal level measurement [20-23]. The detection limits at this laboratory were $0.03 \mu \mathrm{g} / \mathrm{L}$ for cobalt and 0.01 $\mu \mathrm{g} / \mathrm{L}$ for chromium.

Patients in the community laboratory group chose their own laboratory location to have blood drawn. The particular site then chose the location for analysis (National Medical Service, Mayo Clinic, Quest Diagnostic, LabCorp BN lab, IMVH, American Medical Lab and ARUP). Patients from the community laboratory group were prescribed metal level tests at regular intervals including $1,2,3$, and 5 years post-op. We received cobalt levels from 5 different laboratories and chromium levels from 7 different laboratories. Most laboratories used ICPMS to measure metal levels. The normal values and detection limits for each of the community laboratories are summarized in Table 1.

All patients had modular total hip components from a single manufacturer (DePuy, Warsaw, IN). The femoral component was extensively porous-coated and manufactured from a cobalt chromium alloy (AML or Prodigy). The acetabular component was a hemispheric, porous coated cup and made from a titanium alloy (Pinnacle). Modular balls with diameters ranging from $28 \mathrm{~mm}$ to $44 \mathrm{~mm}$ were placed on a 12/14 taper. Matching diameter cobalt chromium alloy inserts of a single design (Ultamet) were placed into the acetabular component with a self-locking taper.
Patients in the community laboratory group tended to be younger than the patients in the reference laboratory group [56.5 \pm 9 (25-88) vs. $63 \pm 10(40-78)$ years old, $\mathrm{p}<0.01, \mathrm{t}$-test $]$. With regards to gender, $57.5 \%(92 / 160)$ of the patients in the community group were male compared to $61.4 \%(35 / 57)$ in the reference group $(\mathrm{p}=0.64$, Chisquare).

\begin{tabular}{|l|l|l|l|l|}
\hline \multicolumn{2}{|l|}{ Laboratory name } & \multicolumn{2}{l|}{ Cobalt level $(\boldsymbol{\mu g} / \mathrm{L})$} & \multicolumn{2}{l|}{ Chromium level $(\boldsymbol{\mu g} / \mathrm{L})$} \\
\hline & $\begin{array}{l}\text { Normal } \\
\text { values }\end{array}$ & $\begin{array}{l}\text { Detection } \\
\text { limit }\end{array}$ & $\begin{array}{l}\text { Normal } \\
\text { values }\end{array}$ & Detection limit \\
\hline \multicolumn{2}{|l|}{ Reference Lab } & & & \\
\hline $\begin{array}{l}\text { London Health } \\
\text { Science Centre }\end{array}$ & $0.03-0.4$ & 0.03 & $0.1-0.2$ & 0.01 \\
\hline Community Lab & $<0.5$ & 1 & $<1.5$ & 0.1 \\
\hline NMS Lab & $<0.9$ & 0.5 & $<0.3$ & 0.1 \\
\hline Mayo clinic & $<1.8$ & 0.5 & $<1.4$ & 0.1 \\
\hline Quest diagnostic & $<0.9$ & 2 & $<2.1$ & 0.1 \\
\hline LabCorp & $<0.4$ & 1 & $<0.2$ & 0.1 \\
\hline ARUP Lab & - & - & $<2.1$ & 0.1 \\
\hline IMVH Lab & - & - & $<1.4$ & 0.1 \\
\hline AML Lab & & &
\end{tabular}

Table 1: Normal values and detection limits for cobalt and chromium levels in serum among various laboratories.

A 36-mm head was the most common size (Table 2). Cobalt and chromium levels from the two groups were reported at follow up intervals. In addition the data from all years were pooled and compared.

\begin{tabular}{|l|l|l|}
\hline Head size & Community Laboratory & Reference Laboratory \\
\hline $28 \mathrm{~mm}$ & 4 & 18 \\
\hline $36 \mathrm{~mm}$ & 136 & 39 \\
\hline $40 \mathrm{~mm}$ & 18 & 0 \\
\hline $44 \mathrm{~mm}$ & 2 & 0 \\
\hline
\end{tabular}

Table 2: Head size distribution in the study population.

For all cases, metal level measurements from the reference laboratory included specific values for both cobalt and chromium. In contrast, community laboratories reported non-detectable values when measurements were under their detection limits. For all community labs, the detection limit for chromium was $0.1 \mu \mathrm{g} / \mathrm{L}$ while the detection limit for cobalt ranged from $0.5-1.0 \mu \mathrm{g} / \mathrm{L}$. Since the actual metal level could be any value below the detection limit, we assigned nondetectable values to half of the detection limit for analysis purposes. However, to fully understand the impact on non-detectable values on our study, we performed additional analyses in which the nondetectable values were assigned a value of zero (lowest possible) and also with assignment of the detection limit (highest possible). These two additional analyses are briefly reported in the manuscript with full tables and figures available in the online appendix. Descriptive 
statistics include means, medians with interquartile ranges, the number of cases below detection limits and the number of cases with values greater than $7 \mu \mathrm{g} / \mathrm{L}$.

For the purposes of illustrating non-parametric data, we used standard box plots that included the median, 25\%-75\% interquartile range, outliers that were 1.5 times the interquartile range. Statistical comparisons were made with SPSS for Windows program (IBM Corp. Armonk, NY). Continuous, normally distributed data were compared with a Student's $t$ test. Non-parametric data was compared with a Mann-Whitney $U$ test. The Institutional Review Board for our facility approved this study.

\section{Results}

The first finding was that every reference group patient had detectable metal level measurements that were characterized by specific numbers. In contrast, for patients in the community laboratory group, between $27-50 \%$ of the cobalt levels were reported as below the detection limit and $1-4 \%$ of the chromium levels were not detectable (Table 3). The three analyses in which cases with metal levels designated as "non-detectable" were assigned a value of either the detection limit, half the detection limit or zero revealed that there was no statistical difference (p-value range 0.09-0.1), with the exception of the first and second year follow-up intervals where the median cobalt level was higher for the community group when the non-detectable values were assigned to the detection limit $(\mathrm{p}<0.001$ and $\mathrm{p}=0.01$, respectively) (Appendix E, F). All other cobalt and chromium comparisons at yearly interval and combined were not different. Therefore, for simplicity of subsequent reporting in this manuscript, all values which were non-detectable are assigned a value half the detection limit for analysis.

\begin{tabular}{|l|l|l|}
\hline Follow-up year & Cobalt & Chromium \\
\hline $1 \mathrm{yr}$ & $36 / 72(50 \%)$ & $1 / 64(1 \%)$ \\
\hline $2 \mathrm{yr}$ & $22 / 51(43 \%)$ & $2 / 49(4 \%)$ \\
\hline $3 \mathrm{yr}$ & $6 / 22(27 \%)$ & $1 / 24(4 \%)$ \\
\hline $5 \mathrm{yr}$ & $13 / 33(39 \%)$ & $1 / 33(3 \%)$ \\
\hline \multicolumn{2}{|l}{ Every patient had a detectable value from reference laboratory } \\
\hline
\end{tabular}

Table 3: Number of cases that had non-detectable values from community laboratories.

The mean serum cobalt level was $3.6 \pm 10.5(0.25-88) \mu \mathrm{g} / \mathrm{L}$ in the community laboratory group and $4.9 \pm 23(0.2-216.3) \mu \mathrm{g} / \mathrm{L}$ in the reference laboratory group. Cobalt levels were not different at any follow up interval or when combined (Figure 1). There was no difference between the number of cases with values greater than $7 \mu \mathrm{g} / \mathrm{L}$ at any time interval or when all values were combined. Overall, $8.9 \%$ of the serum cobalt values were $>7 \mu \mathrm{g} / \mathrm{L}$ in the community laboratory group compared to $7 \%$ for the reference group, $\mathrm{p}=0.5$ (Table 4 ).

The mean serum chromium level was $2.3 \pm 4.5(0.05-37) \mu \mathrm{g} / \mathrm{L}$ in the community laboratory group and $3.0 \pm 10.4(0.23-92.27) \mu \mathrm{g} / \mathrm{L}$ in the reference laboratory group. Trends among for chromium measurements were similar to those for the cobalt levels (Figure 2). There was no difference in either metal levels or the number of values $>7 \mu \mathrm{g} / \mathrm{L}$ at any time interval or when all values were pooled. Overall, $5.3 \%$ of serum chromium values from the community laboratory were
$>7 \mu \mathrm{g} / \mathrm{L}$ compared to $4.7 \%$ from the reference laboratory, $\mathrm{p}=0.78$ (Table 5).

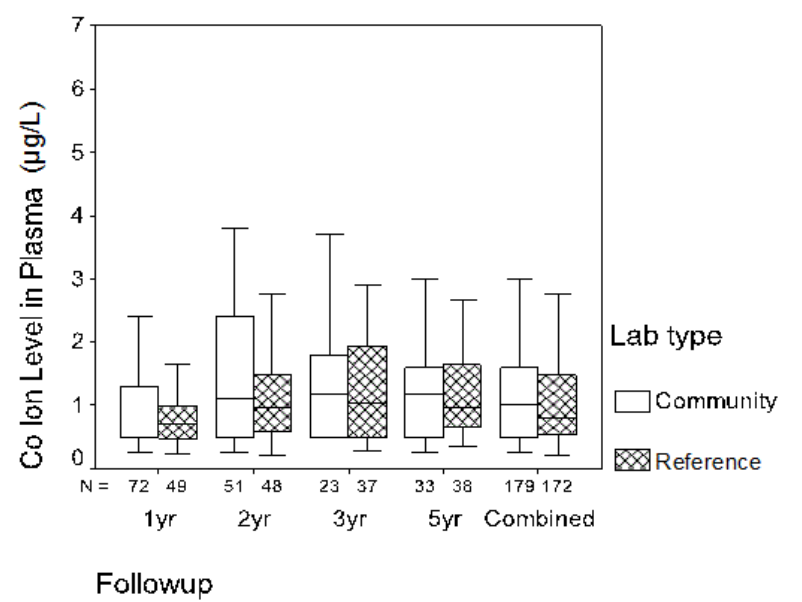

Figure 1: Box-plot diagram of cobalt levels in serum at different follow-up intervals.

\section{Discussion}

Blood metal levels among patients with MOM THAs have been widely reported $[4,9,20,24-28]$. We compared serum cobalt and chromium levels performed at community laboratories to those performed at a reference laboratory. We did not see any difference in the mean values, median values or the number of cases with values greater than $7 \mu \mathrm{g} / \mathrm{L}$ at any time interval or when all values were combined in the comparison of community and reference cobalt or chromium levels. To our knowledge, this is the first study that compares serum cobalt and chromium levels obtained from one group of MOM bearing patients measured at a single reference laboratory to levels from a different group of patients measured at multiple community laboratories. Our results support that the metal levels are similar whether evaluated at a reference or community laboratory and that serum cobalt and chromium levels can be measured in a community laboratory. Based on our findings, physicians should feel comfortable sending patients who need cobalt and chromium metal levels to their local laboratory.

There are weaknesses associated with this retrospective analysis of metal levels. The same patients were tested at each follow-up interval in the reference group whereas the community metal level group was composed of different patients at each time interval. Thus the groups that were compared at each follow-up interval were different. There were more patients in the community laboratory group and they were younger than the reference laboratory patients. While the different patient populations and the fact that multiple laboratories were used for the community laboratory patients could be considered a weakness, it is remarkable that the community laboratories were no different than the tightly controlled reference laboratory group. Another weakness is the high number of community laboratory tests where the metal levels were below the detection threshold. It is unlikely that patients with undetectable values actually had a high value that would be of concern. 
Page 4 of 6

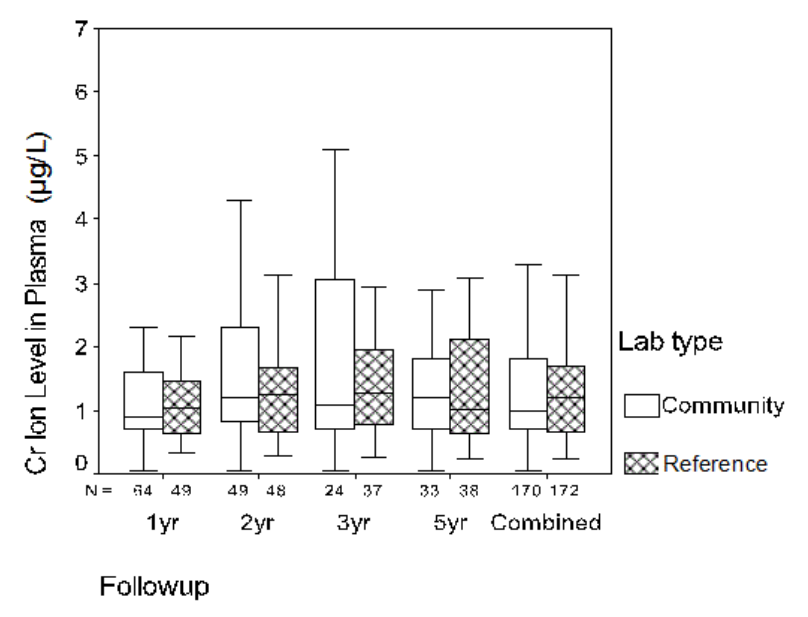

Figure 2: Box-plot diagram of chromium levels in serum at different follow-up intervals.

\begin{tabular}{|c|c|c|c|c|c|}
\hline Cobalt level & $1 \mathrm{yr}$ & $2 \mathrm{yr}$ & $3 \mathrm{yr}$ & $5 \mathrm{yr}$ & Combined \\
\hline \multicolumn{6}{|l|}{ Mean ( $\mu \mathrm{g} / \mathrm{L})$} \\
\hline Community Lab & 2.57 & 5.69 & 2.94 & 2.93 & 3.58 \\
\hline Reference Lab & 2.61 & 4.04 & 7.9 & 6.17 & 4.94 \\
\hline $\begin{array}{l}p \text { value (Student's } \\
\text { t) }\end{array}$ & 0.98 & 0.59 & 0.41 & 0.49 & 0.48 \\
\hline \multicolumn{6}{|l|}{ Median $(\mu \mathrm{g} / \mathrm{L})$} \\
\hline Community Lab & 0.5 & 1.1 & 1.2 & 1.2 & 1 \\
\hline Reference Lab & 0.7 & 0.96 & 1.04 & 0.96 & 0.81 \\
\hline $\begin{array}{l}p \text { value (Mann- } \\
\text { Whitney U) }\end{array}$ & 0.48 & 0.73 & 0.37 & 0.67 & 0.73 \\
\hline \multicolumn{6}{|l|}{$>7 \mu \mathrm{g} / \mathrm{L}$} \\
\hline Community Lab & $4(5.6 \%)$ & $\begin{array}{l}6 \\
(11.8 \%)\end{array}$ & $\begin{array}{l}3 \\
(13.0 \%)\end{array}$ & $\begin{array}{l}3 \\
(9.1 \%)\end{array}$ & 16/179 (8.9\%) \\
\hline Reference Lab & $2(4.1 \%)$ & $3(6.3 \%)$ & $\begin{array}{l}4 \\
(10.8 \%)\end{array}$ & $\begin{array}{l}3 \\
(7.9 \%)\end{array}$ & $12 / 172(7.0 \%)$ \\
\hline $\begin{array}{l}p \text { value (Chi- } \\
\text { square) }\end{array}$ & 0.71 & 0.34 & 0.79 & 0.86 & 0.5 \\
\hline
\end{tabular}

Table 4: Cobalt levels at 1,2, 3, and 5-year follow-up intervals with combined values.

Our findings should not be minimized. At one point, it was estimated that one third of THAs done in the United States used MOM bearings [18]. These patients will need ongoing follow-up for decades in some cases. The United States Food and Drug Administration (FDA) and regulatory agencies in other countries have indicated that metal level data is needed $[2,3]$. Currently metal levels represent one data point in a complex patient-specific decision making process for the care of patients with MOM hips [1]. Recently the focus has been on the relationship between metal levels and the presence of pseudotumors or the need for reoperation $[23,29,30]$. However, long- term concerns about chronic exposure to elevated metal levels remain. It is clear that the need to measure these levels will overwhelm the capacity of reference laboratories. This was the case in a recent MOM implant recall when the recommendations were that metal levels should be drawn and analyzed by one of two national laboratory chains available to patients across the country rather than at a single reference laboratory [17].

We discovered that community laboratories often reported metal levels as below their detection limits. This created a dilemma for data analysis. We chose to assign a value in these cases equal to half the detection limit of the individual laboratory, believing this to be a fair assumption. We tested this assumption by performing additional analyses with all non-detectable values assigned to 0 (the minimum possible value) and the detection limit (the maximum possible value) and have provided the analyses in an online appendix. When the nondetected values were assigned to 0 , we found no statistical difference for cobalt or chromium between the two groups (Appendix A-D). When we set the non-detectable values to the detection limit, we also found no difference for cobalt and no difference comparing chromium values between the reference and community laboratories at 3 and 5 follow-up years (Appendix E-H). Since the reference laboratory data had minimum values that were less than half the community laboratory detection limits, we do not believe that it would be appropriate to use the detection threshold as a value for cases that were not detectable because it represents the maximum possible value for every case with metal levels below the detection threshold. It is also important to note that the patients with no detectable metal levels would not affect the comparison of patients with values higher than $7 \mu \mathrm{g} / \mathrm{L}$. This is important since clinicians and patients are much more concerned about high levels than they are levels below the detection limit.

\begin{tabular}{|c|c|c|c|c|c|}
\hline Chromium level & $1 \mathrm{yr}$ & $2 \mathrm{yr}$ & $3 \mathrm{yr}$ & $5 \mathrm{yr}$ & Combined \\
\hline \multicolumn{6}{|l|}{ Mean ( $\mu \mathrm{g} / \mathrm{L})$} \\
\hline Community Lab & 1.41 & 3 & 3.22 & 2.37 & 2.31 \\
\hline Reference Lab & 1.64 & 2.82 & 3.93 & 3.98 & 2.98 \\
\hline $\mathrm{p}$ value (Student's $\mathrm{t}$ ) & 0.66 & 0.9 & 0.78 & 0.53 & 0.43 \\
\hline \multicolumn{6}{|l|}{ Median $(\mu \mathrm{g} / \mathrm{L})$} \\
\hline Community Lab & 0.9 & 1.2 & 1.1 & 1.2 & 1 \\
\hline Reference Lab & 1.04 & 1.25 & 1.26 & 1.01 & 1.2 \\
\hline $\begin{array}{l}\mathrm{p} \text { value (Mann- } \\
\text { Whitney U) }\end{array}$ & 0.92 & 0.75 & 0.74 & 0.74 & 0.97 \\
\hline \multicolumn{6}{|l|}{$>7 \mu \mathrm{g} / \mathrm{L}$} \\
\hline Community Lab & $1(1.6 \%)$ & $\begin{array}{l}4 \\
(8.2 \%)\end{array}$ & $\begin{array}{l}3 \\
(12.5 \%)\end{array}$ & $\begin{array}{l}1 \\
(3.0 \%)\end{array}$ & $9 / 170(5.3 \%)$ \\
\hline Reference Lab & $1(2.0 \%)$ & $\begin{array}{l}3 \\
(6.3 \%)\end{array}$ & $2(5.4 \%)$ & $\begin{array}{l}2 \\
(5.3 \%)\end{array}$ & $8 / 172(4.7 \%)$ \\
\hline $\mathrm{p}$ value (Chi-square) & 0.85 & 0.72 & 0.32 & 0.64 & 0.78 \\
\hline
\end{tabular}

Table 5: Chromium levels at 1, 2, 3, 5-year follow-up intervals with combined values.

We acknowledge that a better prospective study on this topic might involve using the same specimen and having it analyzed at different 
Page 5 of 6

laboratories. Likewise a patient could have the specimen obtained from more than one site and all specimens analyzed at a single reference laboratory.

These types of prospective studies that isolate both the laboratory performing the analysis and the technique for obtaining the specimen are expensive and beyond the scope of our current research.

We further acknowledge that metal levels are a single piece of data in the complex and evolving management of symptomatic and asymptomatic patients with a MOM bearing.

We did not address the type of test which is best (serum, whole blood, or erythrocyte levels), or what to do with the results of the tests. It is important to emphasize that values which seem inconsistent with an individual patient's presentation should be repeated whether the values come from a reference laboratory or a community laboratory. In addition, metal levels should not be used in isolation when determining the best care for a patient with a MOM hip; instead, the patient history, physical examination and cross-sectional imaging should be reviewed in combination.

In conclusion there is an ongoing need to monitor metal levels in the blood of MOM patients. These patients will need to be monitored for decades. Small or regional reference laboratories are not able to handle the volume of tests that need to be done. We saw no difference in the median cobalt or chromium levels comparing a group of patients who had metal levels ordered, drawn, and tested in our local community laboratories compared to blood drawn following strict research protocols. We believe this study provides support for the concept that community laboratories can provide metal level measurements consistent with the values obtained from patients in controlled research studies using specialized laboratories.

\section{References}

1. Antoniou J, Zukor DJ, Mwale F, Minarik W, Petit A, et al. (2008) Metal ion levels in the blood of patients after hip resurfacing: a comparison between twenty-eight and thirty-six-millimeter-head metal-on-metal prostheses. J Bone Joint Surg Am 90 Suppl 3: 142-148.

2. Bozic KJ, Kurtz S, Lau E, Ong K, Chiu V, et al. (2009) The epidemiology of bearing surface usage in total hip arthroplasty in the United States. J Bone Joint Surg Am 91: 1614-1620.

3. Clarke MT, Lee PT, Arora A, Villar RN (2003) Levels of metal ions after small- and large-diameter metal-on-metal hip arthroplasty. J Bone Joint Surg Br 85: 913-917.

4. De Smet K, De Haan R, Calistri A, Campbell PA, Ebramzadeh E, et al. (2008) Metal ion measurement as a diagnostic tool to identify problems with metal-on-metal hip resurfacing. J Bone Joint Surg Am 90 Suppl 4: 202-208.

5. De Haan R, Pattyn C, Gill HS, Murray DW, Campbell PA, et al. (2008) Correlation between inclination of the acetabular component and metal ion levels in metal-on-metal hip resurfacing replacement. J Bone Joint Surg Br 90: 1291-1297.

6. Delaunay C, Petit I, Learmonth ID, Oger P, Vendittoli PA (2010) Metalon-metal bearings total hip arthroplasty: the cobalt and chromium ions release concern. Orthop Traumatol Surg Res 96: 894-904.

7. Desy NM, Bergeron SG, Petit A, Huk OL, Antoniou J (2011) Surgical variables influence metal ion levels after hip resurfacing. Clin Orthop Relat Res 469: 1635-1641.

8. Engh CA Jr, MacDonald SJ, Sritulanondha S, Thompson A, Naudie D, et al. (2009) 2008 John Charnley award: metal ion levels after metal-onmetal total hip arthroplasty: a randomized trial. Clin Orthop Relat Res 467: 101-111.
9. Ettema HB, GÃnther KP, Schmitt J, Campbell P, Delaunay CP (2013) Consensus statement Current evidence on the management of metal-onmetal bearingsâ€. Hip Int 2-5.

10. Fary C, Thomas GE, Taylor A, Beard D, Carr A, et al. (2011) Diagnosing and investigating adverse reactions in metal on metal hip implants. BMJ 343: d7441.

11. Garbuz DS, Tanzer M, Greidanus NV, Masri BA, Duncan CP (2010) The John Charnley Award: Metal-on-metal hip resurfacing versus largediameter head metal-on-metal total hip arthroplasty: a randomized clinical trial. Clin Orthop Relat Res 468: 318-325.

12. Graves SE, Rothwell A, Tucker K, Jacobs JJ, Sedrakyan A (2011) A multinational assessment of metal-on-metal bearings in hip replacement. J Bone Joint Surg Am 93 Suppl 3: 43-47.

13. Haddad FS, Thakrar RR, Hart AJ, Skinner JA, Nargol AV, et al. (2011) Metal-on-metal bearings: the evidence so far. J Bone Joint Surg Br 93: 572-579.

14. Hart AJ, Sabah SA, Bandi AS, Maggiore P, Tarassoli P, et al. (2011) Sensitivity and specificity of blood cobalt and chromium metal ions for predicting failure of metal-on-metal hip replacement. J Bone Joint Surg Br 93: 1308-1313.

15. Hasegawa M, Yoshida K, Wakabayashi H, Sudo A (2012) Cobalt and chromium ion release after large-diameter metal-on-metal total hip arthroplasty. J Arthroplasty 27: 990-996.

16. http://www.depuy.com/usprofessional-depuy-hip-recall

17. Jacobs JJ, Skipor AK, Campbell PA, Hallab NJ, Urban RM, et al. (2004) Can metal levels be used to monitor metal-on-metal hip arthroplasties? J Arthroplasty 19: 59-65.

18. Jantzen C, Jørgensen HL, Duus BR, Sporring SL, Lauritzen JB (2013) Chromium and cobalt ion concentrations in blood and serum following various types of metal-on-metal hip arthroplasties: a literature overview. Acta Orthop 84: 229-236.

19. Kwon YM, Lombardi AV, Jacobs JJ, Fehring TK, Lewis CG (2014) Risk Stratification Algorithm for Management of Patients with Metal-onMetal Hip Arthroplasty: Consensus Statement of the American Association of Hip and Knee Surgeons, the American Academy of Orthopaedic Surgeons, and The Hip Society. J Bone Joint Surg Am 96: e4.

20. Langton DJ, Jameson SS, Joyce TJ, Hallab NJ, Natu S, et al. (2010) Early failure of metal-on-metal bearings in hip resurfacing and large-diameter total hip replacement: A consequence of excess wear. J Bone Joint Surg Br 92: 38-46.

21. Langton DJ, Joyce TJ, Mangat N, Lord J, Van Orsouw M, et al. (2011) Reducing metal ion release following hip resurfacing arthroplasty. Orthop Clin North Am 42: 169-180, viii.

22. Langton DJ, Sidaginamale RP, Joyce TJ, Natu S, Blain P, et al. (2013) The clinical implications of elevated blood metal ion concentrations in asymptomatic patients with MoM hip resurfacings: a cohort study. BMJ Open 3.

23. Levine BR, Hsu AR, Skipor AK, Hallab NJ, Paprosky WG, et al. (2013) Ten-year outcome of serum metal ion levels after primary total hip arthroplasty: a concise follow-up of a previous report*. J Bone Joint Surg Am 95: 512-518.

24. MacDonald SJ, McCalden RW, Chess DG, Bourne RB, Rorabeck CH, et al. (2003) Metal-on-metal versus polyethylene in hip arthroplasty: a randomized clinical trial. Clin Orthop Relat Res : 282-296.

25. http://www.mhra.gov.uk/Publications/Safetywarnings/ MedicalDeviceAlerts/CON155761

26. Sidaginamale RP, Joyce TJ, Lord JK, Jefferson R, Blain PG, et al. (2013) Blood metal ion testing is an effectivescreening tool to identify poorly performing metal-on-metal bearingsurfaces. Bone Joint Res 2: 84-95.

27. Smith AJ, Dieppe P, Vernon K, Porter M, Blom AW; National Joint Registry of England and Wales (2012) Failure rates of stemmed metal-onmetal hip replacements: analysis of data from the National Joint Registry of England and Wales. Lancet 379: 1199-1204.

28. Tkaczyk C, Petit A, Antoniou J, Zukor DJ, Tabrizian M, et al. (2010) Significance of Elevated Blood Metal Ion Levels in Patients with Metal- 
Citation: Panichkul P, Ho H, Hopper Jr RH, Engh Jr CA (2016) Can Metal Levels be Measured at a Community Laboratory?. J Arthritis 5: 192. doi:10.4172/2167-7921.1000192

Page 6 of 6

on-Metal Prostheses: An Evaluation of Oxidative Stress Markers. Open

30. Information about Soft Tissue Imaging and Metal Ion Testing. Orthop J 4: 221-227.

29. Tower SS (2010) Arthroprosthetic cobaltism: neurological and cardiac manifestations in two patients with metal-on-metal arthroplasty: a case report. J Bone Joint Surg Am 92: 2847-2851. 